DOI: $10.24234 /$ wisdom.v18i2.539

Ruben MIRZAKHANYAN,

Hayk GRIGORYAN

\title{
ARMENIAN APOSTOLIC CHURCH UNDER BOLSHEVIK IDEOLOGICAL AND POLITICAL PRESSURE BETWEEN 1920 AND 1922
}

\begin{abstract}
This article presents the ideological controversies that arose between the Armenian Apostolic Church and the bolshevik regime following the invasion of Soviet troops into Armenia. From its first days in power, Bolshevik authorities implemented radical steps against its ideological rival - the Armenian church. Following the harsh anti-church political line of Russian bolsheviks, the soviet authorities in Armenia started a massive appropriation of Armenian church properties. The article also mentions the first attempts of the soviet administration to organize state institutions to preserve and study national cultural heritage.
\end{abstract}

Keywords: Armenian Apostolic church, Bolshevik ideology, Holy Etchmiadzin, Catholicos of All Armenians, H. H. George V, Revolutionary Committee of Armenia, Council of Salvation of Armenia, the confiscation of the Church's property, the repressions against the clergymen.

\section{Introduction}

The history of any religion assumes a complex study of timelines running along with the corresponding paradigms of beliefs that inspire a cognitive conviction, values which are formed to fill in the vacuum of the regulatory mechanisms of the society; tangible symbolism that covers the human need to detect the necessary bridges of interiorisation of human perceptions and externalisation of human conceptions.

The timelines, most commonly, are traced back through the standardisation of the respective dogma, moral guidance and set of ethical principles, culture, the system of values that gradually infiltrates into the fabric of social life, and eventually, the authority which naturally comprises the Aristotelian triumvirate of rhetorical persuasiveness. Viewed synchronically, the threesome basis of religion comprises the prevailing principles, tangible cultural outcomes, and social norms. On the other hand, the same conceptual pattern of social interaction - viewed diachronically - infers the factors of the for- mation of ethnopsychology, features of ethnic identity, and the constants of institutionalised authority. The complexity of the interrelation of religion and the Church intensifies because the subject-matter domain requires extensive coverage ranging from the intimacy of interpersonal relationship where the participants are viewed individually to the depth and vastness of social interaction respective tendencies are observed. This far-reaching and in-depth scope entails involvement in standardisation in education, social consolidation, public administration, and authority-based counselling.

All the instances that still require scholarly attention and scientific scrutiny are obviously present and valid for the history of the Armenian Apostolic Church. The classical periodisation of the history of the Armenian Church suggests the following stages of development (Petrosyan, 2016, pp. 7-11).

In the old period (from the $1^{\text {st }}$ to the $8^{\text {th }}$ century), which commenced with the spread of the miraculous news about Jesus Christ's activities, the new doctrine disseminated through popular 
channels, penetrating deeply into the routine of social discourse. This viva-voce phase was followed by the phase of proper internalisation of the new teaching based on both evidence and facts, rumours and hopes for miracles, popular counselling and sources of wisdom. Eventually, between the $6^{\text {th }}$ and $8^{\text {th }}$ centuries, the Armenian Apostolic Church's institutional bases were laid in Armenia and the Holy Land.

The middle period (from the beginning of the $9^{\text {th }}$ century to 1441) or the period of flourishment of the Armenian theological schools and Church culture is mainly related to the restoration of Armenia's state independence. Another exciting tendency that highlights the importance of this period is the spread of Christianity through the Armenian Apostolic Church's missions that commenced its spread from the Mesopotamian area to Poland and further European inland. The spread of Armenian Christianity resulted in several centres of the Armenian Apostolic Church all over the area.

The new period - extending from 1441 till the end of the $18^{\text {th }}$ century - more precisely, the new period begins with the return of the Mother See to Holy Etchmiadzin - the place, as the religious legacy claims, initially indicated by Jesus Christ. Together with the continuous and incessant advancement of Christian philosophy and theology, philology and education through the already sophisticated and omnipresent network of Armenian churches, monasteries, schools and universities, the Armenian Apostolic Church keeps safeguarding the national identity from several invaders, from Ottoman Empire expansion, in particular. The immediate involvement of the Church in defence of national identity obliged the Armenian Church Catholicosate to initiate and enhance the interactions and cooperative communication with the major Christian Churches of Europe and the East. The new period - due to intensive educational and scientific efforts, multifaceted support of the development of educational networks - summited one of the zeniths of Armenian academic legacy under the leadership of the Head of the Armenian Apostolic Church, Catholicos, H. H. Movses the Third (Tatevatsi) (1629-1632), whose efforts were proliferated and endured by his disciples and partisan clergymen. The Church's engagement in every aspect of academic character grew into a centralised and utterly systemised national enlightenment mission that had a quality influence - both quantitatively and qualitatively.

The modern period commenced (traditionally dated back to the $19^{\text {th }}$ century) with the involvement of the eastern territories of the Armenian Kingdom in the Russian Empire. From the mid$19^{\text {th }}$ century onwards, the Mother See Holy Etchmiadzin already becomes the scientific and educational centre of Armenia, unifying the Armenian people spiritually and academically and culturally in general. The end century appeared to be particularly drastic and challenging for the Armenian Apostolic Church - the genocide of the Armenian people in Turkey, the fierce World War I, the sovietisation of the eastern territories of Armenia, on the one hand, and the necessity of new and much broader coverage of spiritual mission due to the formation of the Armenian Diaspora all over the world.

As it becomes evident from the glimpse of the history of the Armenian Apostolic Church, this spiritual pillar of the Armenian culture has been shaped up and perfected under a series of hardships, controversies, discrepancies and consolidation, ups, and downs which have ultimately endorsed the priority of its mission interlacing the Christian Church with the cultural legacy which kept integrally rooted in the Armenian mentality, lifestyle, more broadly speaking, Armenian culture.

The year 1920 was of fatal significance and vortical for Armenia and the Armenian People. The establishment of the Soviet regime brought about new ideological thinking - with all the respective consequences which tossed a new challenge before the Armenian Apostolic Church.

The new authorities brought about a new ideology in political, economic, cultural, and religi- 
ous spheres. In fact, not only the public administration but also the system of religious doctrine were overthrown. We would like to make a particular reference to that very system of religious ideology as the gap that emerged wide open in the society. After the establishment of the new regime, this gap should necessarily be filled in by a new ideology. And the new power seemed to have been preparing for that for a rather long time.

Both in Russia and Armenia, after the establishment of the Soviet regime, a new "witchcraft" was launched against the antirevolutionary forces, including the Armenian Apostolic Church. It should be noted that the bolshevik movement had already been conducting a fierce struggle against the ideology of the Church since the beginning of the century. Nevertheless, that movement is a different topic that might deserve a separate exploration into the matter. The Bolshevik leaders would oppose their ideology to religion. Therefore, they did consider the Church as their primary rival. In the Russian Social-Democratic Labour Party, A. Lunacharsky was the most prominent activist of this mission. He did his best in order to oppose religion to science, highlighting the scientific bases of socialism. According to him, science is a system that has nothing to do with emotions, love or hope - unlike religion (Lunacharskiy, 1911, p. 24). In fact, the new political power would reject any mission or role in society's life that might be attributed to belief. Instead, they suggest that there should be a new model implemented - the scientific socialism - that would, in its turn, over time, be substituted by scientific communism. These new ideological bases were meant to replace the vast country's ideology full of a variety of religions, creeds and beliefs, generating new "spiritual" leaders and beliefs.

Armenia, where the Soviet regime was established in December of 1920, could not but fall victim to those developments. The new political power launched its struggle against antirevolutionary forces targeting, first of all, the Armenian
Apostolic Church. Once the new ideology seized power, they recalled the Church's position about the events that happened in May of 1920: Catholicos of All Armenians, H. H. George V criticised quite categorically the activities of the rebels who stood against the Armenian authorities under Dashnaktsutyun Political Party and the Republic of Armenia. The Head of the Armenian Church expressed his disapproval of the posture of bolshevik rebels who would position themselves as saviours, meanwhile, in fact, distorting the country (Stepanyants, 1994, p. 4). Moreover, after the bolshevik attempt of rebellion, the Holy See formulated a covenant that was meant to regulate the relations between the state and the Church. The covenant referred to the significant issues related to economic autonomy, diplomatic mission, and the Church and clergy members' safety and immunity. Thus, this covenant was supposed to guarantee a semi-autonomous and almost-free status for the Armenian Apostolic Church (Kertogh, 2018, pp. 314-317). Nevertheless, in December, after the sovietisation of Armenia, the Church appeared in a rather grave situation, and the draft of the covenant was considered worthless.

On December 2, 1920, Dashnaktsutyun Political Party peacefully transferred the power to the Bolshevik forces according to the Yerevan agreement. According to the Yerevan agreement of 1920, no repressions or persecutions might be exercised against the representatives of Armenia's previous authorities or socialist parties. The National Army's military commandment was also recognised as free of any responsibilities for all the activities before establishing soviet power in Armenia (Klyuchnikov \& Sabanin, 1928, pp. 75-76). The agreement, however, contained no reference to the Armenian Apostolic Church. This absence of any documented statement might entail that the new authorities would not assume any responsibility for the Church or the priesthood. Such legal negligence was likely to lead to the same or similar policy already enacted by the Bolsheviks in Soviet Russia. On January 
20, 1918, by the decree of the Council of People's Commissars of Soviet Russia, the Church was officially separated from the state with further confiscation of the Church property, accompanied by the repressions against the clergymen. On May 27, 1920, the decision passed by the Commissar of Justice Kursky was released to cease the existence of all the dioceses in Russia (National Archive of Armenia, Fond 57, List 3, Entry 146, File 2). This, consequently, referred to the dioceses of the Armenian Apostolic Church in Russia, about which, a little bit later, of course, the Armenian Catholicos, H.H. George V was warned by the Diocis Council of South Caucasus and Astrakhan (National Archive of Armenia, Fond 57, List 3, Entry 146, File 24). Thus, the clergymen were well aware of the possible policy that Armenia's new authorities might adopt towards the Church.

According to the new political power's ideology, the Armenian Church was viewed as a remnant of the previous regime and a hurdle for promulgating the new doctrine. A few days after signing the Yerevan agreement, on December 7, the related activities against the Church commenced. The Head of the Revolutionary Committee of Vagharshapat Koryun Grigorean shuts down the paper warehouse of the printing house and all the warehouses of the office sector of the Holy See. Two days later, the letterpresses and bindery were confiscated, and the book warehouse was closed down as well (Behbutyan, 1996, p. 146). We should note that there was no decree about confiscating the Church property yet. In 1920, the Printing House of Mother See of Holy Echmiadzin published the volume dedicated to the $100^{\text {th }}$ anniversary of one of the most prominent Heads of the Armenian Church, late Catholicos Khrimian Hayrik, authored by Hayk Achemyan, Karapet Kostanyants's poetry selection, and what was particularly important and relevant for the time, the Code of light artillery, cannon manoeuvres, and mountain artillery. These volumes, utterly crucial for the army, were released with the respective bilingual (Armenian-Russian) terminological glossary. In 1921 and 1922, the printing house released calendars only - Armenian Christian Calendar 4115-4416 and $\mathrm{n} 3<\mathrm{L}-$ f-1371-2, as well as Armenian Christian Calendar 4416-4417 and ก-3<U-Q-1372-3.

In fact, it was already supposed that the new authorities were going to be guided by the same principles as those which the same authorities had been applying for over two years in Russia. However, after the sovietisation of Armenia, not only political activists and military contingent but also clergymen were arrested. Among the Armenian clergymen arrested were the Vardapet (Archimendtrite and Theology Professor) Yeznik Nerkararyan, Head of the parish of the village of Dovr in Ashtarak, Member of the Armenian Revolutionary Party, Father Gregory Ter-Petrosyan, hermit of the eremitic congregation of Aghtamar and Lim, hermit of Mother See of Holy Echmiadzin, one of the heroes of the self-defence movement in Van, Archimandrite and Theology Professor Daniel Zadoyan, hermit of the Mother See of Holy Echmiadzin, Archimandrite-teacher Tadevos Harutyunyan (Kertogh, 2018, p. 339).

On December 17, the Revolutionary Committee of Armenia released a decree according to which all the cultural and educational institutions that belonged to the Republic's religious communities were supposed to be nationalised and transferred under the control of the People's Commissariat of Enlightenment (Communist, 1920). The same day, by the People's Commissar of Enlightenment of Armenia Ashot Hovhannisyan's decree, all the institutions mentioned above were transferred under the control of the local administrative bodies except for the Seminary, Archeological and Ethnographic Museums, the Deposit of ancient manuscripts and printing house of Mother See of Holy Echmiadzin which were supposed to keep working under the immediate supervision and control of the Commissariat of Enlightenment. Moreover, already on December 20, Levon Lisitsyan was appointed Commissar for educational and cultural institutions, embarking the next day on the mission of confis- 
cating the monastic complex of the Holy See (Sukiasyan, 2014, p. 97). That was, definitely, a severe blow for the Church.

However, we should note that together with the confiscation, Lisitsyan seemed to be trying to preserve historical-cultural values. In his report submitted on December 23 to the People's Commissar Ashot Hovhannisyan, he provides a detailed account of his efforts. At the same time, he asks to give the deposit mentioned above of manuscripts and the museum with the necessary professional personnel. Moreover, L. Lisitsyan asks to delegate the architect Toros Toramanyan to Echmiadzin so that he could supervise the activities of preserving the architectural monuments of the region (National Archive of Armenia, Fond 122, List 1, Entry 228, File 2-3).

According to the reports sent by Lisitsyan to the People's Commissar Ashot Hovhannisyan, it becomes clear that the first task to be accomplished was to confiscate the whole property of Etchmiadzin for which every single valuable item was involved in a special list to be informed about to the new authorities. Simultaneously, the Commisar Lisitsyan, who was now in charge of all the monastic educational and cultural institutions of Echmiadzin, was trying to take care of these institutions, communicating his worries about the historical and cultural monuments. He obviously thought that the manuscripts and other historic materials archived in Matenadaran - the deposit of ancient manuscripts - should not remain as mere archive items if not should be studied and published. The materials compiled and preserved in Etchmiadzin offered massive resources for historic-archaeological and philological studies. That was the main reason for creating a scientific institute that would generate new cultural values and reveal its "significance for propaganda and political prospects" (Evoyan, 1972, pp. 183-196). Therefore, it should be stated that in parallel with the task to confiscate the Church's property, there was another mission to abolish the Christian theological insight freeing the necessary room for propagating the new ideology using modern propaganda methods. Thus, the decree of the Commissariat of Enlightenment of the Armenian Soviet Socialist Republic issued on December 31, 1920, was one of the pieces of evidence of those intentions since it banned delivering any discipline of religious character and the celebration of any religious rite in schools (Manukyan, 1996, p. 188).

The gravest blow against the Armenian Church, after the sovietisation of the country, was that mandate 600 issued on January 26, 1921, entitling the People's Commissar of Enlightenment of Armenia, A. Hovhannisyan, to confiscate all the valuable items and attributes of the religious rite that belonged to the Church (which were officially declared as out of use) to hand them over to the newly created state museum (National Archive of Armenia, Fond 57, List 2, Entry 2252, File 1). On February 2, the Secretary-speaker of Mother See of Holy Echmiadzin Bishop Koryun introduced to the grand sacristan of the Mother Cathedral, Bishop George Chorekchyan, a letter on the mission delegated to him the previous day by the Head of the Armenian Church. According to that letter, in order to avoid potential concerns, they were supposed to form a particular mission group consisting of the hermits of the Mother See, holy fathers archbishops Anania and Husik, as well as involving Bishops Mesrop and Matthew. The list of the items to be handed over to the museum was supposed to be introduced to the Catholicos only upon whose approval the items could be taken out of the Mother Cathedral. The Head of the Armenian Church also asked to convey his desolation and resentment to the People's Commissar Hovhannisyan for the fact that during a couple of months, the Soviet authorities had already nationalised much more valuable items belonging to the Church and the Mother See without the Patriarch's awareness or consent. Meanwhile, those items "belonged to the whole Armenian Nation and His Holiness is a mere guarantee of the heritage and not the owner of those items" (National Archive of Armenia, Fond 57, List 2, 
Entry 2252, File 2). Despite the clergy members' resentment, they were absolutely helpless to initiate any procedures against the Soviet authorities.

On February 2, 1921, the first organisational meeting of the Cultural-historic Institute of Etchmiadzin was held. It was chaired by the People's Commissar A. Hovhannisyan. The People's Commissariat was assigned to restructure the institutions' network (the deposit of manuscripts, museum, printing house, etc.) nationalised in Etchmiadzin and establish an institute for historical and cultural studies in Etchmiadzin. The decree passed was the first legal document that allowed the formation and actual operation for about a month of the first institution of science in Armenia - the Institute of Culture and History of Etchmiadzin. The Institute's activities were interrupted in 1921 because of the antisoviet riot that happened in February (Sukiasyan, 2014, p. 100).

On February 5, the decree "On the handing over the property of Etchmiadzin to the Commissariat of Enlightenment" passed by the Revolutionary Committee of Armenia allowed nationalising the Mother See's property, handing over some part of it to the Commissariat of Enlightenment. As a result, the latter gained absolute control over St. Hripsimeh Monastery, the ruins of the medieval Temple of Zvartnots, the new block of the Patriarchal Residence and other buildings (Communist, 1921).

Hence, the Bolsheviks, acquiring power, commenced a massive aggressive campaign against the Armenian Apostolic Church. They made use of the first months of their term to devastate almost completely the Church's bases. It was pretty natural that such policy adopted by the Bolsheviks would provoke discontent among the priesthood. A similar wave of discontent started to gain ground across all the social layers and different political circles.

In February 1921, a rebellion busted out in Armenia, and on February 18, the power in Yerevan already belonged to Dashnaktsutyun Polit- ical Party. That rebellion raised serious hopes, first of all, at Mother See Holy of Etchmiadzin as the victory of that political power could assume freedom from repressions and the return of property to its previous owner.

With weapons in their hands, the religious representatives took part in the rebellion that took place in different parts of Armenia. Among them, there were the Head of the parish of the village of Dovr in Ashtarak, Priest Grigor TerPetrosyan, the Head of the parish of the village of Dokhs in Vagharshapat, Priest Ghevond Zakaryan, the Head of the parish of the village of Bazarchay in Sisian, Priest Harutyun Ter-Vardanyan, the Head of the parish of the village of Byrakan in Ashtarak, Priest Gegham Ter-Hovhannisyan and others (Kertogh, 2018, 343).

On February 19, the Holy See turned to the Head of the Council (Committee) of Salvation of Armenia, Simon Vratsyan, stating that the institutions of national importance confiscated by the majoritarian political power (bolsheviks) from the Mother See of Holy Etchmiadzin had been returned to the previous administration (National Archive of Armenia, Fond 57, List 3, Entry 216, File 1). However, the Salvation Committee issued a decree according to which those institutions were to retain their status remaining under the governmental administration. The Primate of Ararat Diocesis, Archbishop Khoren Muradbekyan, asked to meet Simon Vratsyan as the latter had personally assured Father Khoren (on February 26) that the whole property confiscated from the Holy See would be returned (National Archive of Armenia, Fond 57, List 3, Entry 216, File 2). The meeting took place only on March 21. In his report submitted to the Catholicos on March 23, the Archbishop details the meeting he had together with Father Koryun - the Secretary of the Mother See of Holy Echmiadzin. The meeting was also attended by the first Prime Minister of Armenia, H. Kajaznuni. Archibishop Khoren accuses the Salvation Committee of endorsing the Bolshevik regime and of designating a new Commissar. S. Vratsyan tries to equivo- 
cate, answering, "The Committee for the Salvation of Armenia that is currently operating, has assumed the responsibility to clean the country of Bolsheviks, establish peace and then to give the power to the people who will form their government and that government will already be entitled to make decisions as for all the issues" (National Archive of Armenia, Fond 57, List 3, Entry 216, File 2). Naturally, this answer could not satisfy the Archbishop who informed Simon Vrastyan that there was considerable discontent among ordinary people with the Salvation Council as the Council "wished to maintain the status of the institutions of Echmiadzin determined by the Bolsheviks" (National Archive of Armenia, Fond 57, List 3, Entry 216, File 2). The Church wouldn't understand the equivocating policy of the new government, especially if we take into consideration the fact that among the soldiers of the military contingent of the new authorities, there were a lot of clergymen who stood up, first of all, struggling for the rights of the Church.

Nevertheless, for the sake of the truth, we should state that the Salvation Committee itself didn't know how much they would be able to maintain the power as, since mid-March, the Bolsheviks had initiated their counterattacks. As Hovhannes Kajaznuni stated, "the functions assumed by the Salvation Council were temporary" (National Archive of Armenia, Fond 57, List 3, Entry 216, File 2). On April 2, the $18^{\text {th }}$ rifle division units led by A. Shirmacher entered Yerevan. As a matter of fact, the power again was transferred to the Bolsheviks. A particular part of the clergymen who took part in the rebellion was pardoned, while some were arrested. The Deputy Head of New Bayazet, archimandrite-professor Yeznik Vardanyan, was suffocated in the Lake Sevan ice pit as an antisocialist element (Kertogh, 2018, p. 347). Simultaneously, in Syunik, the local clergymen and the newly formed Lernahayastan (Arm.: "Mountainous Armenia") unit kept struggling against the Bolsheviks. Moreover, they would provide the re- publican forces who retreated to Syunik with necessary weapons (Kertogh, 2018, p. 348).

During the rebellion in February, the Mother See of Holy Etchmiadzin made a decision according to which the seal of the Holy See with the double-headed eagle of the Russian Empire, endorsed according to the decree of 1836, was supposed to be changed with a new seal with the image of Saint Echmiadzin in the centre and with the inscription "Saint Echmiadzin Synod" (National Archive of Armenia, Fond 57, List 3, Entry 227 , File 2 ). That was probably the only step that the Church could take during the days of the rebellion. The religious authorities didn't manage to return the property usurped.

Thus, in the period between December and May of 1920, the Bolshevik authorities managed to strike the Armenian Apostolic Church: shaking the church system and distorting the system of Church and religious values established for centuries. The Bolshevik authorities aimed at creating an ideological vacuum that was meant to be filled with the new ideology. The Church was standing in the way of that ideology. For that aim, it was essential to debilitate the Church economically so that they could achieve the primary objective that they had set. On the other hand, the hopes of the clergymen related to the Salvation Committee headed by the Dashnaktsutyun political party didn't come true. The religious layer was to put up with that reality and adopt a more watchful policy towards the Bolsheviks who seized power back. The Bolshevik authorities, in their turn, also grew observant as for their internal policy. On May 21, 1921, the Soviet Socialist Republic of Armenia's Revolutionary Committee was transformed into the Council of People's Commissars (CPC). Alexander Myasnikyan was appointed as the Chairman of the Council. This leader's figure is related to the moderate policy towards the Armenian Apostolic Church, in particular. The Church was mainly being treated with a certain degree of tolerance.

After the Soviet Troops had usurped the pow- 
er again, on April 16 and April 18, according to the order of the Patriarch of the Armenian Church, the Members of Etchmiadzin Congregation met the Chair of the Revolutionary Committee of Armenia S. Kasyan. The meeting was also attended by the Chairman of the Revolutionary Committee of Vagharshapat Melik-Shahnazaryan, People's Commissar in charge of foreign affairs A. Mravyan, Military Commissar A. Nurijanyan, and other high-ranked officials. During the meeting, the issues of the property confiscated from Holy Etchmiadzin were raised. At the same time, the new authorities were informed of the critical role that Etchmiadzin assumed as a unifying centre for Armenians both within Armenia and beyond its boundaries. The Armenian clergymen also made use of the opportunity to request reopening the higher-education spiritual school - the Seminary - asking for an arable piece of land for the Mother See so that the Church could meet the respective needs (Behbutyan, 1996, p. 132). After hearing the Congregation Members' request, S. Kasyan informed them that the Soviet authorities had never set obstacles to the Church's activities, simultaneously alluding that the Church had acted against the new authorities supporting the Dashnaktsutyun power. Quite naturally, the clergymen present denied (Behbutyan, 1996, p. 133).

As we have already introduced, during the events in February, several religious people took part in the activities against the soviet government. Nevertheless, we shouldn't forget about the policy that the Bolsheviks adopted against the Church after having seized power in the country. Most probably, in order to mitigate the tension, the Soviet authorities headed by Kasyan agreed to make some concession. On April 19, Echmiadzin was visited by the People's Commissar for agricultural affairs, who asked the religious centre to submit their request about farming lands in writing (Behbutyan, 1996, p. 133). That was, most probably, the first concessive step taken by the Soviet authorities towards the Church. It was pretty understandable that any strict policy was likely to entail negative consequences only. Simultaneously, it should be noted that Soviet Russia had already opted for a milder and more tolerant policy towards the Church. Most probably, both these factors contributed to the change of attitude towards the Church.

In May 1921, we can see that the Soviet authorities started to make concessions and express disposed to return the lands that had not been conceded to the local community members or organisations (National Archive of Armenia, Fond 57, List 2, Entry 642, File 2). On September 20, 1921, the Council of the People's Commissars of the Soviet Socialist Republic of Armenia passed the decision to return the museum, St. Hripsimeh, St. Gayaneh monasteries and a part of the orchards belonging to the monasteries (National Archive of Armenia, Fond 57, List 3, Entry 313, File 2). On March 10, 1922, the Board of the People's Commissariat in charge of agricultural affairs returned all the lands, except for the two orchards near Zvartnots, under the ownership of the Church, i.e. to their original proprietor (Behbutyan, 1996, p. 144). The museum of Echmiadzin was also transferred under the supervision of the Head of the Mother See. Moreover, as we see, even the central authorities kept persuading the local government bodies not to interfere in Etchmiadzin's affairs (Behbutyan, 1996, p. 144).

However, the policy of concessions didn't last long. On November 17, 1921, by a special decree, the clergymen were deprived of the right to vote and be elected, and according to Article 6 of the Constitution passed on February 2, 1922, by the Councils of Armenia, the Church was recognised as separated from the state and education. That status assumed that the Church ended up deprived of the rights attributable to a legal entity, consequently enabling the authorities to commence a new, this time even more fierce campaign against the Church (Manukyan, 1996, p. 188). Despite the statement of "the freedom of any religious and antireligious propaganda" in the Constitution, which seemed to provide the 
Church with the respective freedom, the authorities factually adopted an opposite attitude to the Church and faith due to the belief that "the Church may not be observed at the same level alongside the Trade Unions, neither with the institutions that work in favour of science, enlightenment and the social layer of workers" (Hovhannisyan, 2014, p. 100).

After this Constitution had been passed, the persecutions against the Mother See of Holy Etchmiadzin became even more intense. The separation of the schools from the Church had a serious impact on Holy Etchmiadzin.

Starting from the middle of 1922 , the pressure against the Church kept growing, becoming obvious from 1932 in particular. A variety of fake religious organisations contradicting the Church were created. Those fake formations were meant to distort the Armenian Apostolic Church through discrepancies, trying to abolish the Church's bases.

\section{Conclusion}

After the establishment of the Soviet regime, the new authorities initiated the process of quick abolishment and the evidence of the historical memory of the Church. The Armenian Bolsheviks conducted the same policy in Armenia as their counterparts had started to enact in Russia since 1917 though de jure Armenia was considered independent, which inferred that there was no need to mirror the policy adopted by another state. The confiscation of the Church's property, the repressions against the clergymen, and the antihuman attitude applied to different social layers provoked massive discontent among the population, which, in its turn, ended up in the armed overthrow of the political power in February 1921. After seizing power back, the Bolsheviks, in the beginning, seemed to alleviate their tough policy against the Church, returning a specific part of the Church property confiscated to its owner. Nevertheless, this didn't last long, and already in 1922, the same authorities came up with even more intensified policy against the Church.

\section{References}

Behbutyan, S. (Ed.) (1996). Vaveragrer hay yekeghetsu patmut'yan, girq B, Xoren A. Muradbekyan Kat'oghikos Amenayn Hayoc (hogevor gorc'uneut'yuny 19011938 t'.t.')(Documented sources of the history of Armenian Church, Book 2, Catholicos of All Armenians Khoren A. Muradbekyan (spiritual activities in 1901-1938), in Armenian). Yerevan: Anahit.

Evoyan, V. (1972). P'astat'ght'er L\&von Lisitsyani masin (Documents on Levon Lisitsyan, in Armenian). Banber Hayastani arxivneri (Bulletin of the Archives of Armenia, in Armenian), 1, 183-196.

Hovhannisyan, E. (2014, January). Martnchogh anastvac'neri miut'yan gorc'uneut'yuny Xorhrdayin Hayastanum 1920-1930 -akan t'vakannerin (The activities of belligerent atheists in Soviet Armenia in the 1920s and 1930s, in Armenian). Etchmiadzin (Etchmiadzin, in Armenian), 100-107.

Kertogh, S. (2018). Hay ar'aqelakan Surb yekeghecu gorc'uneut'yuny' Hayastani arajin hanrapetut'yan tarinerin (Activities of Saint Armenian Apostolic Church during the years of the first Republic of Armenia, in Armenian). Etchmiadzin: S. Etchmiadzin.

Klyuchnikov, Yu., \& Sabanin, A. (1928). Mezhdunarodnaya politika noveishego vremeni $\mathrm{v}$ dogovorakh, notakh i deklaraciyakh. Ch. III. Ot snyatiya blokady s Sovetskoi Rossii do desyatiletiya Oktabr'skoi revolyutsii. Vyp. 1 Akty sovetskoi diplomatii. (International Policy in the contemporary period through agreements, diplomatic notes, and declarations, in Russian), From lifting the blo- 
ckade from Soviet Russia to the decade of the October Revolution, Issue 1. Soviet Diplomatic Acts). Moscow. Litizdat NKID.

Komunist (Communist, in Armenian) (1920, December 18). Yerevan.

Komunist (Communist, in Armenian) (1921, February 8).Yerevan.

Lunacharskiy, A. (1911). Religiya i sotsializm (Religion and Socialism, in Russian). (Vol. 2). Saint Petersburg: Shipovnik.

Manukyan, A. (1996). Yekeghecin Hayastanum 1930-akan t'vakannerin (The Church in Armenia in the 1930s, in Armenian). Banber Er\&ani hamalsarani (Bulletin of Yerevan University, in Armenian), 2(89), 188-199.

National Archive of Armenia, Fond 122, List 1, Entry 228, File 2-3.

National Archive of Armenia, Fond 57, List 2, Entry 2252, File 1.

National Archive of Armenia, Fond 57, List 2, Entry 2252, File 2.

National Archive of Armenia, Fond 57, List 2, Entry 642, File 2.

National Archive of Armenia, Fond 57, List 3, Entry 146, File 2.
National Archive of Armenia, Fond 57, List 3, Entry 146, File 24.

National Archive of Armenia, Fond 57, List 3, Entry 216, File 1.

National Archive of Armenia, Fond 57, List 3, Entry 216, File 2.

National Archive of Armenia, Fond 57, List 3, Entry 313, File 2.

Petrosyan, Y. Archbishop (2016). Hay yekeghecu patmut'yun, Mas 1 (History of the Armenian Church, Part 1, in Armenian) ( $7^{\text {th }}$ ed.). Yerevan: Bible Society of Armenia.

Stepanyants, S. (1994). Hay araqelakan yekeghecin stalinyan brnapetut'yan oroq (The Armenian Apostolic Church under Stalin's repressions, in Armenian). Yerevan: Apolon.

Sukiasyan, H. (2014). Yekeghecu sepakanut'yan brnagravumy' Xorhrdayin Hayastanum (1920 dektember - 1921 p'etrvar) (Confiscation of the Church property in Soviet Armenia (December 1920 February 1921), in Armenian). Lraber hasarakakan gitut'yunneri (Bulletin of Social Sciences, in Armenian), 1, 95102. 